\title{
Federal States and Equality in Political Representation
}

\author{
Federalism Superseding Democracy?
}

\author{
Sérgio Ferrari
}

\section{Introduction: Aim and Outline of the Research}

This chapter aims to present a brief reflection on the distribution of seats in the lower chamber of Brazilian parliament and its possible impact on the principle of equality and democracy.

The survey was based on empirical data concerning the number of representatives from each state and the number of voters. All data was obtained from publicly available government sources. From simple calculations, there was the possibility of verifying that the division of seats, as provided for in Brazilian legislation, leads to an imbalance in the representation of citizens from different States.

This chapter will proceed with the following outline: chapter 2 will present the one person, one vote principle as well as its practical application. In addition, the relationship between such a principle and democracy will be discussed. Chapter 3 will point out some elements of formation of parliaments in federal states, bicameralism and the reasons for its adoption. In this chapter, the methods for the constitution of the lower house and the need to distribute seats between certain groups of the electorate, territorially determined, will also be considered. In chapter 4, basic data about Brazil and its Constitution will initially be shown so that the reader can more easily understand the problem to be examined. Then, the numbers obtained in the empirical survey and their impact on equality among voters will be analysed. In this chapter, the causes of the distortion found will also be discussed. In chapter 5 , possible measures to solve or mitigate the distortion will be appraised, discussing the advantages and disadvantages of each one. Finally, in the conclusion (chapter 6), the arguments and possible solutions will be taken up, with the opinion of the author. 
The relationship between democracy and equality is almost intuitive. Every human being enjoys the same dignity and is entitled to the same possibilities to participate in the decision-making of the community.

The term one man, one vote (today, more appropriately, one person, one vote) often designates such a rule of equal representation in the United States Constitution, as stated in the 14th Amendment, 1868, Section 2:

Representatives shall be apportioned among the several States according to their respective numbers, counting the whole number of persons in each State, excluding Indians not taxed. ${ }^{1}$

Historically, the idea of universal suffrage was a conquest that took many centuries to happen. Women and ethnic minority groups were denied political rights. Nowadays, there is a general consensus that the principle of equality requires every human to be equally represented in the deliberative chambers of the country. In this sense, equality is an essential requirement for democracy.

This idea is widely accepted by scholars, as Snyder and Samuels say:

Although scholars vigorously dispute the exact meaning and definition of democracy, wide agreement exists that free and fair elections are the cornerstone of any democratic system of government. An essential characteristic of electoral 'fairness' in democracies is that the vote of each citizen counts equally. This notion of fairness embodies the well-known principle of 'one person, one vote' that theorists such as Robert Dahl consider a necessary ingredient of democracy. ${ }^{2}$

1 Indigenous people, under American law, have a special legal regime; they are not considered subject to the sovereignty of the states or the central government, which is called 'triadic federalism': 'Indeed, Indian tribes today continue to possess important governmental authority over their lands and members. The rationale is that tribes were sovereign before European contact and have retained all pre-existing sovereignty that (1) remains consistent with the tribes' 'dependent status', (2) has never been ceded away by them by treaty, and (3) has never been pre-empted by federal statute.' Daniel A. Farber, William N. Eskridge Jr., Philip P. Frickey. Constitutional Law (St. Paul: Thomson West, 2003), 1048.

2 Richard Snyder and David J. Samuels, "Legislative Malapportionment in Latin America," in Federalism and Democracy in Latin America, ed. Edward L. Gibson (Baltimore: The John Hopkins University Press, 2004), 131. 
It is also present in the Universal Declaration of Human Rights (article 25) ${ }^{3}$ and in the American Convention on Human Rights (article 23). ${ }^{4}$ A similar statement is found in article 14 of the Brazilian Constitution. ${ }^{5}$ Moreover, this assumption leads to the idea that every vote is worth the same. Ideally, each member of the parliament should represent the same number of citizens.

In this section, representation in federal states and its repercussions on the principle of equality among citizens will be analysed. In the first part (3.1), bicameralism, the reasons for its adoption in federal states and the division of chairs in the upper chamber will be discussed. In the second part (3.2), the formation of the lower house and the difficulties of finding a method that meets proportionality between the states and, therefore, equality between citizens will be specifically analysed.

Bicameralism and the Reasons for Its Emergence: The Formation of the Upper House

The federal form of state, despite some characteristic traits in previous historical periods, ${ }^{6}$ had its genesis in the foundation of the United States of America. ${ }^{7}$ In addition, the American Constitution of 1787 influenced the Constitutions

3 The will of the people shall be the basis of the authority of government; this will shall be expressed in periodic and genuine elections which shall be by universal and equal suffrage and shall be held by secret vote or by equivalent free voting procedures.

4 Every citizen shall enjoy the following rights and opportunities:

a. to take part in the conduct of public affairs, directly or through freely chosen representatives;

b. to vote and to be elected in genuine periodic elections, which shall be by universal and equal suffrage and by secret ballot that guarantees the free expression of the will of the voters.

5 Art. 14. Popular sovereignty will be exercised by universal suffrage and by direct and secret vote, with equal value for all.

6 Daniel Elazar, Exploring Federalism (Tuscaloosa: The University of Alabama Press, 1987), xii.

7 Sanchez Agesta says about the importance of the USA example: 'The founders of Philadelphia had a very clear idea of the problems they had to solve and of the solution with which they wanted to solve them. Few times we find in History, with so much evidence, the root of institutions'; Luis Sanchez Agesta, Curso de derecho constitucional comparado (Madrid: Universidad de Madrid, Facultad de Derecho, 1976), 178. 
of Latin American countries that gained independence in the nineteenth century, ${ }^{8}$ including Brazil.

During the formation of the US federation at the Philadelphia Convention, discussions took place on how best to balance the representation of States. As can be read in the Federalist Papers (n. 62I) 'The Equality of representation in the senate is another point, which, being evidently the result of compromise between the opposite pretensions of the large and the small states, does not call for much discussion. ${ }^{9}$

The main issue in federations is the need to represent citizens individually but also the constituent states in a reasonably balanced way. Thus, the bicameral formation emerges as a solution to this question. According to George Anderson's summary, the representation of constituent units, in almost all federations, leads to a bicameral organisation. ${ }^{10}$

However, this formula of bicameralism already generates some distortion: the population of less populous states will have a larger representation in the upper chamber. Therefore, it means there are two factors present in federal states, which must be taken into account in the distribution of seats of parliament: equal representation of citizens and equal representation of constituent units. If only one of such factors is considered - as it usually is in the upper chambers - clearly, the other will be impaired. This impairment will be more extensive, proportionally to the difference of population between the constituent units. Hueglin and Flenna show some examples of inequality in the upper chamber, including the critical case of the USA."

8 'While the federations of Latin America followed American governmental design very closely, these institutional similarities tend to obscure the fact that the Latin America road to federalism was quite different.' Thomas O. Hueglin and Alan Fenna. Comparative Federalism: A Systematic Inquiry (Quebec: Broadview Press, 2005), 133.

9 Alexander Hamilton, John Jay and James Madison, The Federalist, eds. George W. Carey and James McClellan (2001), 320, http://files.libertyfund.org/files/788/oo84_LFeBk.pdf.

10 'Almost all the federations count on a high chamber whose composition, in some way, represents the constituent units. The prevalence of upper chambers thus configured in federations is associated with the idea that both the population and the constituent units are parts of the federation and that these two dimensions need to be reflected in the central institutions'; George Anderson, Federalismo: uma introdução (Rio de Janeiro: FGV, 2009), 69 .

11 'The path of equal representation was taken by the Americans, conforming naturally to their original confederal approach under the Articles and carried over to the final Constitution. This results in 'massive overrepresentation' of the small states; modern-day California is awarded only the same number of Senate seats as Wyoming despite having 66 times the population. Among the classical federations, only Australia and, with a minor variation, Switzerland has followed this example - and in Australia malapportionment at this most extreme is only 14 to one (New South Wales versus Tasmania)'; Thomas 
That is why we do not need to be afraid to say that, in this specific point, federal arrangement is not democratic. Preston King points it out in a clear way:

First, the voting populations of the different territorial units in federations are always of unequal size, sometimes dramatically so. Since the votes of citizens in some territories will have greater force than those of citizens in other states, federations must in this sense, and in varying degree from case to case, prove undemocratic. ${ }^{12}$

Regarding specifically the Brazilian case, George Anderson presents the following numbers: 'At one extreme is Brazil, where senators from states that together comprise $8 \%$ of the national population occupy more than $50 \%$ of seats. ${ }^{13}$ In the extreme, there are Roraima (177 thousand people for each senator) and São Paulo (14.5 million people for each senator).

Therefore, in short, it is possible to say that, in a federal state, the adoption of bicameralism is justified because:

- The upper chamber is supposed to represent states, guaranteeing the same number of chairs for each of them and

- The lower chamber is supposed to represent citizens, distributing the seats proportionally to the population or the electorate of each state.

This statement is deliberately a simplification. We know there are federal states that do not adopt bicameralism. There are also federal states where representation of states in the upper house is not entirely equal. These exceptions, however, do not invalidate the above findings.

The overrepresentation of some citizens in the upper house, in this sense, can be an important guarantee for the representation of minorities. If the upper house already performs this function, the lower house must, on the other hand, guarantee, to the greatest extent possible, the equality of citizens' representation. Understanding this point is the only reason why this chapter discusses bicameralism and its role in federations. The purpose of the chapter is to analyse exclusively the formation of the lower chamber in a federal state and how its criteria can impact equality.

An interesting approach to representation in federal states is offered by Francesco Palermo, who suggests that, in order to guarantee more

O. Hueglin and Alan Fenna, Comparative Federalism: A Systematic Inquiry (Quebec: Broadview Press, 2005), 181.

12 Preston King, Federalism and Federation (Baltimore: The Johns Hopkins University Press, $1982), 88$.

13 Anderson, Federalismo: uma introdução, 71. 
representation and participation to local interests, we should focus on analysing the phenomenon of bilateralism. ${ }^{14}$ Bilateralism, in this context, can be understood as the process of cooperation and direct understanding between a single local government and the central government, without the aspect of collective deliberation that characterises multilateral bodies. ${ }^{15}$

Nevertheless, the focus of this chapter is the lower chamber. It will be discussed in the next chapters, regarding the Brazilian case.

\subsection{The Lower Chamber and Its Formation}

As seen above, the composition of the lower chamber should be proportional to the electorate of each state (one person, one vote ...) so that it may be capable of representing citizens equally. Also, in federations, states are usually electoral districts. For this reason, the ratio between the number of citizens and the number of seats assigned to each state becomes a very important issue.

At this point, it is possible to say that bicameralism can offer a balance between the two factors mentioned above, that is, equality of representation between citizens and equality of representation between constituent units. Clearly, disproportional representation of citizens in the upper house is a price to pay for the federative balance. ${ }^{16}$ The option for federalism brings with it the acceptance of this difference between the citizens of the states regarding the representation in the upper house. The assumption, however, is that in the lower house the representation of citizens is as egalitarian as possible. So far, there is nothing new.

However, when, in addition to the natural imbalance of representation of citizens in the upper house (a fact inherent in almost all federations), there

14 'While the political and scholarly discourse too often looks at how second chambers could be made more effective in representing subnational interests, it forgets that the issue is participation, that participation takes place outside of second chambers and that, in a growing number of cases, the main problem is to determine the right balance between individual and collective bargaining between the levels of government'; Francesco Palermo, "Beyond Second Chambers: Alternative Representation of Territorial Interests and Their Reasons," Perspectives on Federalism 10, no. 2 (2018).

15 'This is why more and more frequently strong subnational units pursue bilateral instruments for negotiation and cooperation with the national level and very often such fora are legally established since the national level acknowledges that they are necessary. Francesco Palermo, "Beyond Second Chambers: Alternative Representation of Territorial Interests and Their Reasons," Perspectives on Federalism 10, no. 2 (2018).

16 'Federations, then, sacrifice in some degree citizen equality in order to secure, again in some degree, regional equality. King, Preston. "Federalism and Representation," in Comparative Federalism and Federation, eds. Michael Burgess and Alain-G. Gagnon (London: Harvester Wheatsheaf, 1993), 101. 
is also an overrepresentation of some constituent units in the lower house, there is an excessive impairment to equality among citizens. In this sense, it is understood that the federal organisation can mean a threat to democracy.

In federal states, there is a division of chairs, in lower chamber, among the states. Therefore, since members of congress must be elected by the votes of only a single state, territorial division can cause an impact on equality of representation. Hence, there is a clear relationship between the division of territory (one of the key subjects of studies on federalism) and equality in representation: if the states are different in population or density, it is often hard to find a mathematical formula to preserve equal representation.

Proportionality in the representation of citizens of different states may seem a simple task, but, indeed, it is not. The first problem concerns only mathematics. As a starting point, let us take the division of the total population of a country by the number of seats in the lower chamber, obtaining a 'quotient'. Then, we divide the population of each state by this quotient. The result should indicate how many inhabitants each congressperson represents. However, the division will rarely be exact, i.e., resulting in a counting number. If the result indicates that state A should have 5.6 representatives, and state B must have 2.4 representatives, which state should assign the chair, A or B? Also, if a state has a population below the quotient, can it remain without representation?

Almost all Constitutions of federations require that each constituent unit must have at least one representative in the lower house. This point is highlighted, for instance, in the Swiss system of dividing the 200 seats of the lower house, ${ }^{17}$ as well as in the formula of the US Constitution. ${ }^{18}$ Despite the different solutions adopted in each federation, the minimum of one representative per constituent unit has an obvious basis: if a constituent unit without representatives were possible, its citizens would simply not be represented in parliament,

17 'In the first round, the total number of all inhabitants is divided by 200. Cantons that have a population of less than the determined number receive one seat. These cantons and their share in the Swiss population are excluded from the further procedure. In the second round, the remaining population is divided by the remaining seats. Again, the cantons whose population is less than the determined number receive one seat, and they and their populations are, from then on, excluded from the procedure. This procedure is repeated until all remaining cantons have populations higher than the determined number. In the third round, for the distribution of remaining seats, the population of each remaining canton is divided by the last determined number'; Thomas Fleiner, Alexander Misic and Nicole Töpperwien, Constitutional Law in Switzerland (Alphen aan den Rijn: Stämpfli Publishers, 2012), 89 .

18 Article I, section 2, clause 3: 'The Number of Representatives shall not exceed one for every thirty Thousand, but each State shall have at Least one Representative.' 
which would mean the annulment of their citizenship. This conclusion, however, will only be valid if we have as an insuperable dogma the idea that a citizen can only be represented in the lower house,by another citizen of the same state.

A second mathematical problem is the assignment of minimum and maximum numbers of representatives per constituent unit. This tends to damage the more populous states and favour the less populous. From a strictly arithmetic point of view, it is quite clear that citizens of more populous constituent units are underrepresented, in comparison with citizens of less populous ones (overrepresented). In my view, a simple breach of the rule one person, one vote is enough to characterise an impairment to equality of representation and, consequently, to democracy. It is true that the functionality of the system may require toleration of some distortion, at least in extreme cases (very populous or very sparsely populated constituent units). Nevertheless, the preservation of equality and democracy means that we must always seek the formula that minimises these problems as much as possible.

Finally, in a time perspective, population may vary over time from one constituent unit to another in a different way. Taking any period of time, a constituent unit may have a higher population growth than another one. This may be due to demographic differences such as higher birth rates or longevity in some states. However, the most common cause in Brazil is migration within the country. ${ }^{19}$ This is especially dramatic in countries with high social inequality, such as Brazil, where workers from the north and northeast regions tend to migrate to the southeast region, in search of jobs and a higher quality of life. Hence, rules of division of chairs must be periodically updated. In case such updates prove to be impossible, flexible rules should at least be adopted, in order to modify the division with a simple update of population numbers. If there are no updates (of rules or information), such distortion tends to increase over time.

From this topic, the Brazilian case will be specifically addressed, in three subtopics. In the first, some general information will be presented for a better understanding of the local context, especially for the foreign reader. In the

\footnotetext{
19 Jairo Nicolau, Representantes de quem? Os descaminhos do seu voto da urna à Câmara dos Deputados (Rio de Janeiro: Zahar, 2017), 99.
} 
second topic, Brazilian constitutional and legal rules on the formation of the lower house will be exposed, as well as the figures resulting from the application of these rules. In the third, the effects of these results on the principle of equality will be discussed.

\subsection{The Context: Key Facts about Brazil}

As an overview, the Brazilian federation is made up of 26 states and one federal district. The total population estimated for 2017 is 207.7 million people. ${ }^{20}$ For study purposes, the country is usually divided into five regions: north, northeast, centre-west, southeast and south. ${ }^{21}$ The southeast is where most of the population is concentrated, while the north and centre-west have great territorial extension and smaller population, resulting in low demographic density. ${ }^{22}$ The northern region holds large, still-preserved forests and indigenous populations. ${ }^{23}$ The centre-west is currently one of the world's largest producers of animal protein and grains, especially soybeans. ${ }^{24}$ The north and northeast have the worst indicators of development and quality of life. ${ }^{25}$ The south and southeast regions have higher rates of development and some cultural homogeneity between them. More than $40 \%$ of the population is

20 IBGE (2017), https://agenciadenoticias.ibge.gov.br/agencia-sala-de-imprensa/2013-agenciadenoticias/releases/16131-ibge-divulga-as-estimativas-populacionais-dos-municipios-para 2017\#: :text=O\%2oIBGE\%2odivulga\%2ohoje\%2oas,2016\%2o(०\%2C80\%25).

21 IBGE (2020), https://www.ibge.gov.br/geociencias/organizacao-do-territorio/divisaoregional/15778-divisoes-regionais-do-brasil.html?=\&t=o-que-e. The states of each region are: North: Amazonas (AM), Pará (PA), Acre (AC), Rondônia (RO), Amapá (AP), Roraima (RR) and Tocantins (TO); Northeast: Maranhão (MA), Piauí (PI), Ceará (CE), Rio Grande do Norte (RN); Pernambuco (PE), Alagoas (AL), Paraíba (PB), Sergipe (SE) and Bahia (BA); Centre-West: Mato Grosso (MT), Mato Grosso do Sul (MS), Goiás (Go) and the federal district - Distrito Federal (DF); Southeast: Espírito Santo (ES), Minas Gerais (MG), Rio de Janeiro (RJ) and São Paulo (SP); South: Paraná (PR), Santa Catarina (SC) and Rio Grande do Sul (RS).

22 IBGE (2010a), https://censo2010.ibge.gov.br/sinopse/index.php?dados=10\&uf=oo. Agência Brasil (2019), https://agenciabrasil.ebc.com.br/economia/noticia/2019-10/estudo-dizque-sudeste-reune-maior-numero-de-residentes-422\#: :text=A\%2oregi\% $\% \mathrm{C}_{3} \% \mathrm{~A}_{3} \% 2 \mathrm{O}$ Sudeste $\% 20 \% \mathrm{C}_{3} \%$ A9\%2oa,Oeste $\% 20\left(7 \% 2 \mathrm{C}_{7} \% 25\right)$.

23 Ministério do Meio Ambiente (2020), https://www.mma.gov.br/informma/item/8746regiao-norte.html.

24 CONAB (2019), https://www.conab.gov.br/institucional/publicacoes/perspectivas-para-a -agropecuaria.

25 IPEA(2019),https://www.ipea.gov.br/portal/index.php?option=com_content\&view=article\&id=34681\&Itemid=7\#: :text=Em\%2O2017\%2C\%200\%20\%C3\%ADndice $\% 20$ atingia,era $\% 2$ oinferior $\% 20$ oo $\% 2$ odo\%2opa $\% \mathrm{C}_{3} \% \mathrm{ADs}$. 
concentrated in only three states of the federation (São Paulo, Minas Gerais and Rio de Janeiro), all in the southeast region. ${ }^{26}$ The three coastal states of the southeast region (Rio de Janeiro, São Paulo and Espírito Santo) produce more than $95 \%$ of Brazilian oil. ${ }^{27}$ For this reason, they also have a predominant share of royalty revenue.

Although there are variations between states, none of them significantly concentrates any ethnic or religious group, which are scattered over the country. The uniformity of the language is almost total, since only a very small part of the population (indigenous people still living in isolation) do not speak Portuguese. ${ }^{28}$ Regional variations of the language are irrelevant.

In summary, Brazilian states and regions are highly homogeneous as to the key factors that most commonly identify minorities in need of protection: nationality, ethnicity, religion and language.

Presidentialism is the system of government, with a president elected directly every four years, on the same date as the legislative elections. Only a second consecutive term is allowed for the president, with no limits for nonconsecutive periods. Voting is mandatory for all Brazilians between 18 and 70 years of age, and it is optional for those between the ages of 16 and 17 and those over 70 . In the 2016 elections, there were 144 million people eligible to vote. ${ }^{29}$

The 26 states and the Federal District have their own parliaments (with a single chamber), directly elected by citizens according to the one person, one vote principle. However, its relevance is narrow. All important legislative matters, according to the Constitution, must be regulated by federal laws and, therefore, passed in the national parliament. ${ }^{30}$

26 IвGE (2017), https://agenciadenoticias.ibge.gov.br/agencia-sala-de-imprensa/2013agencia-de-noticias/releases/16131-ibge-divulga-as-estimativas-populacionais-dosmunicipios-para2017\#: :text=O\%2oIBGE\%2odivulga\%2ohoje\%2oas, 2016\%2o (о\%2C80\%25).

27 ANP (2019) http://www.anp.gov.br/publicacoes/anuario-estatistico/5237-anuario-estatistico -2019 .

28 According to the latest official information available (2010 census), $17.5 \%(143,144)$ of indigenous people $(817,963)$, who represent $0.08 \%$ of the total population $(190,755,799)$ do not speak Portuguese. IBGE (2010b), censo2010.ibge.gov.br/https://indigenas.ibge.gov. $\mathrm{br} /$ graficos-e-tabelas-2.html.

29 TSE (2016), http://www.tse.jus.br/imprensa/noticias-tse/2016/Novembro/segundo-turno -municipios-com-biometria-tem-indice-menor-de-abstencoes.

30 Marcelo Piancasteli. "The Federal Republic of Brazil," in Distribution of Powers and Responsibilities in Federal Countries, eds. Akhtar Majeed, Ronald L. Watts and Douglas M. Brown (Montreal: McGill-Queen's University Press, 2006), 81. 
Brazilian Constitution clearly establishes the role of each house: the Chamber of Deputies is composed of representatives of the people and the Federal Senate is composed of representatives of the states. ${ }^{31}$

The Senate is composed of three representatives from each constituent unit (26 states and the federal district), totalling eighty-one senators. Each senator has a mandate of eight years. Renewal occurs every four years, alternating one of three and two of three, i.e., one senator per state in one election, and two senators per state in the next election, and so on. Election occurs through the majority system, that is, the most voted are elected, regardless of party. ${ }^{32}$

\section{2}

The Formation of the Brazilian Lower Chamber: Rules and Numbers

For the composition of the Chamber of Deputies, candidates within the same state compete for the chairs allocated to that constituent unit. Voters in each state can only vote for candidates from that state. Election obeys the proportional system, that is, the seats are divided between parties according to the total votes for each party, in that state. ${ }^{33}$

The total number of deputies is determined by complementary law. ${ }^{34}$ The Constitution further determines that the number of representatives per state must be proportional to its population. However, the Constitution itself (not an ordinary law) also establishes a minimum of eight and a maximum of seventy deputies per constituent unit. ${ }^{35}$

It is important to note that the role of each chamber in the legislative procedure is very similar. Both are equally important in the law-making and in the oversight of the Executive Branch. Ordinarily, every law must be passed

31 Art. 44: "The Legislative Power is exercised by the National Congress, which is composed of the Chamber of Deputies and the Federal Senate.'

32 Art. 46: 'The Federal Senate is constituted of representatives of the States and the Federal District, elected according to the majority principle; Paragraph 1: Each State and the Federal District shall elect three Senators, with a term of eight years.'

33 Art. 45: 'The Chamber of Deputies is composed of representatives of the people, elected by the proportional system, in each State, in each Territory and in the Federal District.'

34 The complementary law ('lei complementar') is a special type of law whose subject to be regulated is previously determined by the Constitution. Its approval requires an absolute majority (more than half of the members of the whole chamber), while the ordinary law ('lei ordinária') may be passed by a simple majority (more than a half of those present).

35 Art. 46 Paragraph 1: "The total number of Deputies, as well as the representation by State and by the Federal District, shall be established by complementary law, proportionately to the population, with the necessary adjustments, in the year preceding the elections, so that none of those units of the Federation has less than eight or more than seventy Deputies.' 
in both chambers successively. In addition, several deliberations are bound to the Congresso Nacional (National Congress), which consists of the unicameral meeting of the two chambers.

The Complementary Law 78 of 1993, which complements these norms, thus establishes that the maximum number of federal deputies is 513 , the most populous state must have seventy deputies and none of them shall have less than eight (repeating what the Constitution settles). Furthermore, information from the official statistics institute must be used to calculate the distribution of chairs between states. ${ }^{36}$

The last general revision of the composition of the Chamber of Deputies took place in 1986. Subsequently, seats were added only to some states, reaching the number of 513 , which has remained the same since 1993. Therefore, for almost 25 years, the division of seats between constituent units has been unchanged, despite the variation of total population and also in each constituent unit.

These rules contained in Brazilian laws generate great distortion in the representation of the states in the lower chamber. Table 11.1 shows the number of representatives (second column, 'A') and inhabitants (third column, 'B') in each constituent unit. In the fourth column, the number of citizens represented by each representative is shown. This results from a simple division between the number of inhabitants (third column) and the number of representatives per constituent unit (second column). In the fifth column, there would be the number for each State, if an exact proportion were adopted (the 'ideal' number). In order to calculate the exact proportion, 513 seats were divided between the constituent units, without considering the minimum of eight and the maximum of seventy. In the fifth column is the difference, more or less, in that number of representatives.

This difference can be seen in Figure 11.1 below, where the bars indicate the number of citizens represented by each Member of the lower chamber by state (the 'C' factor in the table above).

The midpoint would be situated at 394,658 citizens, so that seven constituent units are underrepresented. On the other hand, twenty constituent

36 Art. 1: 'Proportional to the population of the States and the Federal District, the number of federal deputies shall not exceed five hundred and thirteen representatives, provided by the Brazilian Institute of Geography and Statistics Foundation, in the year prior to the elections, the demographic statistical update of the units of the Federation.'

Art. 2: 'None of the member states of the Federation shall have less than eight federal deputies.'

Art. 3: 'The most populous State shall be represented by seventy federal deputies.' 
TABLE 11.1 Number of representatives and inhabitants per constituent unit in Brazil

\section{Constituent unit Representatives Inhabitants Division Exact Distortion proportion}
(A)
(B)
$\mathrm{C}=\mathrm{B} / \mathrm{A}$
(D)
$(\mathrm{A}-\mathrm{D})$

\begin{tabular}{|c|c|c|c|c|c|}
\hline \multirow{2}{*}{ São Paulo (SP) } & \multicolumn{3}{|c|}{$'(2010)$} & \multirow[b]{2}{*}{110} & \multirow[b]{2}{*}{-40} \\
\hline & 70 & $43 \cdot 592.011$ & 622.743 & & \\
\hline Minas Gerais (MG) & 53 & $20.5^{24.700}$ & $387.25^{8}$ & $5^{2}$ & 1 \\
\hline Rio de Janeiro (RJ) & 46 & $16.868 .85^{1}$ & 366.714 & 43 & 3 \\
\hline Bahia (BA) & 39 & 14.517 .499 & 372.244 & 37 & 2 \\
\hline $\begin{array}{l}\text { Rio Grande do Sul } \\
\text { (Rs) }\end{array}$ & 31 & 10.959 .601 & $353 \cdot 536$ & 28 & 3 \\
\hline Paraná (PR) & 30 & 10.917 .904 & 363.930 & 28 & 2 \\
\hline Pernambuco (PE) & 25 & 9.275 .121 & 371.005 & 24 & 1 \\
\hline Ceará (CE) & 22 & 9.022 .175 & 410.099 & 23 & -1 \\
\hline Pará (PA) & 17 & 8.390 .051 & $493 \cdot 53^{2}$ & 21 & -4 \\
\hline Maranhão (MA) & 18 & 7.096.909 & 394.273 & 18 & $\mathrm{O}$ \\
\hline Santa Catarina (SC) & 16 & 6.753 .006 & 422.063 & 17 & -1 \\
\hline Goiás (GO) & 17 & 6.581 .240 & $387.13^{2}$ & 17 & $\mathrm{O}$ \\
\hline Paraíba (Рв) & 12 & $3 \cdot 941.613$ & 328.468 & 10 & 2 \\
\hline Espírito Santo (ES) & 10 & $3 \cdot 746.205$ & 374.621 & 9 & 1 \\
\hline Piauí (PI) & 10 & 3.266 .919 & $3^{26.692}$ & 8 & 2 \\
\hline Alagoas (AL) & 9 & 3.283 .025 & 364.781 & 8 & 1 \\
\hline Rio Grande do & 8 & 3.387 .060 & 423.383 & 9 & -1 \\
\hline Norte (RN) & & & & & \\
\hline Amazonas (AM) & 8 & 3.877 .243 & 484.655 & 10 & -2 \\
\hline Mato Grosso (MT) & 8 & $3 \cdot 342.705$ & 417.838 & 8 & $\mathrm{o}$ \\
\hline $\begin{array}{l}\text { Mato Grosso do Sul } \\
\text { (Ms) }\end{array}$ & 8 & 2.660 .685 & 332.586 & 7 & 1 \\
\hline $\begin{array}{l}\text { Distrito Federal } \\
(\mathrm{DF})\end{array}$ & 8 & 2.882 .625 & 360.328 & 7 & 1 \\
\hline Sergipe (SE) & 8 & $2.227 \cdot 984$ & 278.498 & 6 & 2 \\
\hline Rondônia (RO) & 8 & $1.663 \cdot 797$ & $207 \cdot 975$ & 4 & 4 \\
\hline Tocantins (то) & 8 & 1.513 .492 & 189.187 & 4 & 4 \\
\hline $\operatorname{Acre}(\mathrm{AC})$ & 8 & 841.66 o & 105.208 & 2 & 6 \\
\hline Amapá (AP) & 8 & 794.181 & 99.273 & 2 & 6 \\
\hline Roraima (RR) & 8 & 531.053 & 66.382 & 1 & 7 \\
\hline TOTAL & 513 & $202.459 \cdot 315$ & 394.658 & 513 & \\
\hline
\end{tabular}




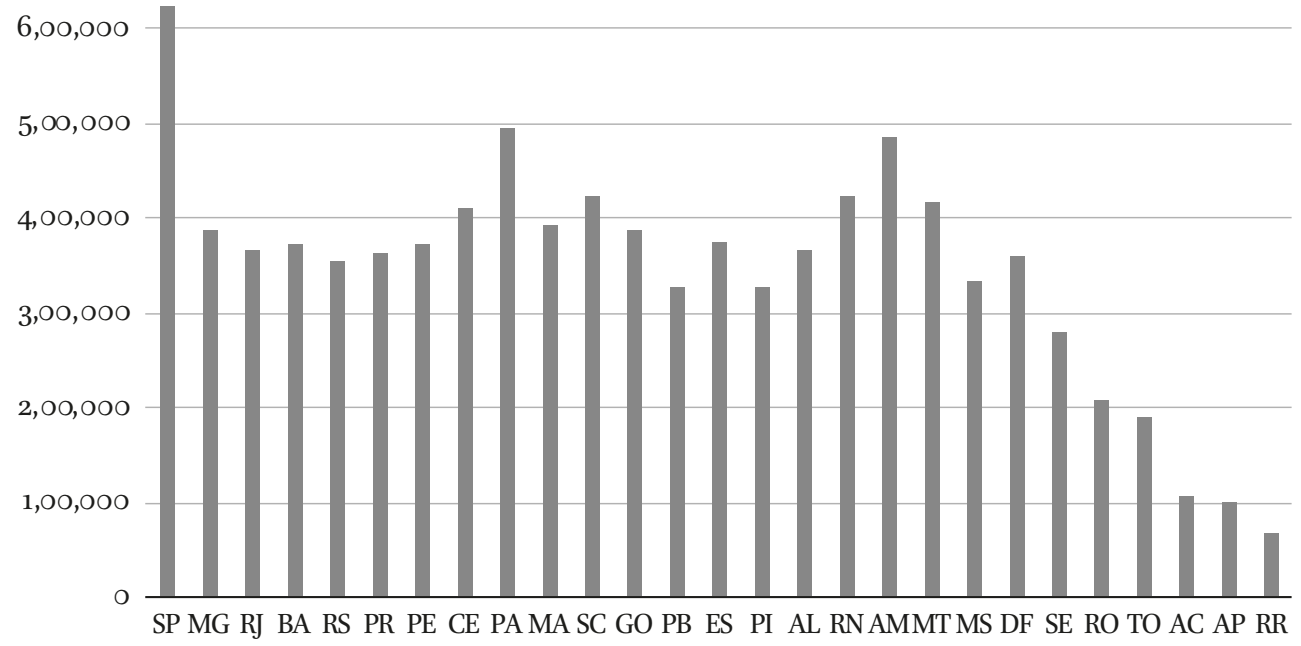

FIGURE 11.1 Citizen representation by members of the lower chamber by state

units are consequently overrepresented. However, the overrepresentation is proportionally very large. As shown, there is a huge difference between the population of the states, from 43 million people in São Paulo to 0.5 million in Roraima. However, the Constitution determines a range from eight to seventy representatives for each state, and a total number of 513. According to such numbers (settled by the Constitution, not only by a regulation), Brazil is an excellent example of the mathematical impossibility of a totally equal representation. Very briefly, it means there is overrepresentation in the lower chamber of less populated states, mainly by the northeast and the north regions.

\subsection{Consequences of Distortion: Is It a Real Problem?}

The correlation between democracy and federalism is almost a commonplace in studies of federations. In very succinct terms, the greater decentralisation of power between different constituent units would, in the most common view, lead to greater citizen participation and, consequently, bring them closer to a democracy. According to Ronald Watts:

Democracy and governmental responsiveness can be enhanced within federations because multiple levels of government maximize the 
opportunity for citizen participation and because they provide for governments that are smaller and closer to the people. ${ }^{37}$

In spite of recognising the predominance of this view, some scholars, such as Alfred Stepan, ask for more research to confirm this statement. ${ }^{38}$

Regarding the specific issue of the present chapter, numbers alone demonstrate that the rule one person, one vote is seriously impaired in such a situation of inequality. There is clear inequality between citizens of different constituent units, which results from overrepresentation or underrepresentation. If there is no equality of representation, it cannot be said that democracy is whole.

In a non-federal state, inequalities in representation are also possible. However, the problem is certainly less severe because there is more flexibility for adjustments. The division of electoral districts could be done on the basis of equality of representation, with no limits in the borders of constituent units. On the contrary, in federal states, the limit of electoral districts, in the grid of borders of constituent units, makes it more difficult to manage distortions.

However, in a federation, the mandatory election of representatives within each state results in distortions. Such distortions can be more or less serious in each federation, for the reasons already mentioned above: mathematical problems, minimum and maximum number of representatives per state and internal migration (without periodic revisions of the representation of each state).

It cannot be denied, then, that the federal form of state can be, from such a point of view, less democratic, due to the distortion of the proportionality of representation in the lower chamber (which is supposed to represent the people) and the breaking of the principle one person, one vote.

In other words, when seeking formal equality between constituent units that are quite different, federalism leads to political inequality between citizens of different states. In the lower chamber, if the organisational model does not follow proportionality (for example, determining minimum and maximum numbers of representatives for each constituent unit), the result could be the inequality between citizens of different states.

37 Ronald L. Watts. Comparing Federal Systems (Montreal: McGill-Queen's University Press, 2008), 155 .

38 'Some advocate federalism, as opposed to unitary government, because they believe it contributes to freedom, subsidiarity and democracy. I have not seen any systematic evidence to support these assumptions, but they clearly need to be researched'; Alfred Stepan, "Toward a New Comparative Politics of Federalism, Multinationalism and Democracy," in Federalism and Democracy in Latin America, ed. Edward L. Gibson (Baltimore: The Johns Hopkins University Press, 2004), 74. 
In addition, researching some Latin American cases, including Brazil, Snyder and Samuels revealed important consequences of this distortion:

Specifically, the high levels of malapportionment in Latin American countries have fostered: (1) a rural-conservative bias in legislature, (2) estrangement of the executive and legislative branches, (3) the proliferation of subnational authoritarian enclaves and (4) a strong capacity for subnational elites to 'hold the center hostage' with regard to major policy issues. 39

Could such distortion be considered a benefit, rather than a problem? In other words, could it be said that this overrepresentation of some states is a way of protecting minorities, which, in the end, is one of the key ideas of federalism?

There are two answers: a more general one and a specific one for the Brazilian case.

In a more general perspective, if the citizens of smaller states are already overrepresented in the upper house, it does not make sense to give them an overrepresentation in the lower house as well. The role of the lower house, as seen, is to represent all citizens, regardless of the constituent unit in which they live. Therefore, there is no reason why the principle of equality should not be respected to the greatest extent possible in the lower house.

In Brazil, ethnic and religious groups are spread over several states, making it impossible to feature any state as representative of any minority. As for the language, the homogeneity of the Brazilian population is almost total. Therefore, overrepresentation of any state, just because it has fewer inhabitants, does not bring any benefit to minorities.

Further reflection is necessary: why should each state be an electoral district? Why have all federations, since the beginning, adopted this 'rule'? Is it part of the federal concept?

From the first federations, the election of representatives has been made by constituent units. It is as old a tradition as the federal form of state. In federations formed by aggregation of units (such as the United States and Switzerland), the historical reason seems fairly clear: the people of each state or canton elect their representatives to a central body. Each constituent unit already existed before the federation and the national parliament.

39 Richard Snyder and David J. Samuels, "Legislative Malapportionment in Latin America," in Federalism and Democracy in Latin America, ed. Edward L. Gibson, (Baltimore: The John Hopkins University Press, 2004), 151. 
However, in countries like Brazil, where their states were never independent, nor did they form a confederation, there is no such historical reason. So, the maintenance of this dogma (election of representatives only within the limits of each constituent unity) is the result only of a long tradition. It is not part of the federal concept. Simply, as far as is known, no different way has ever been attempted.

Possible Measures to Solve or Mitigate the Problem

At this point, I will discuss some suggestions for measures to solve or mitigate the problem of distortion of citizens representation in Brazil.

\subsection{An Almost Absolute Proportion}

One first idea would be to adopt an absolute proportion, determining the number of citizens that would be represented by each of the deputies, without establishing any maximum by states, and the minimum of one (this is the reason for the almost in the subsection title), but keeping the total size of the lower chamber. It means that the minimum number of representatives by state shall be one. In addition, a periodic review of the division would be important in order to take into account the internal migratory movements that could alter the population of the states. ${ }^{40}$ The obvious advantage of this system would be the closest possible approximation to the principle one person, one vote.

On the other hand, such a solution could generate another distortion, since some states would have only one deputy and three senators. In this situation, it would be easier to be elected to the upper chamber than to the lower one.

\subsection{Developing Bilateralism}

In Brazil, a more extensive practice of bilateralism could go through the creation of interstate representation bodies for a collective dialogue with the central government. These bodies could be created by region, or by specific interests (oil producing states, for example), in order to make this dialogue more efficient. These ideas, however, would depend on deeper changes in the system and, therefore, on extensive and difficult changes in the Constitution.

Encouraging bilateralism would not exactly be a solution to the problem, but only a mitigating measure. With space for dialogue and discussion between

40 Jairo Nicolau argues that the periodic review should be done every four years, before each election, in order to eliminate this factor of distortion; Nicolau, Representantes de quem?, $155^{-157}$ 
the constituent units and the central power, especially about the most controversial issues, citizens representativeness would be favoured, albeit indirectly.

\subsection{One State, Two or More Electoral Districts}

Observing the figures in the table above (Table 11.1), it is noted that the most serious problem of underrepresentation is in the State of São Paulo. This is an extensive state with a large population. In this sense, the idea of dividing it into two electoral districts would be reasonable, so that each of them would have the number of deputies proportional to its electorate, according to the rules of the Constitution.

To implement this idea, it would be necessary to break the paradigm, present in many federal states, that each constituent unit constitutes a single electoral district. This procedure would encounter great difficulty, as it would depend on a constitutional amendment, with approval by three-fifths of each chamber of the parliament. In addition, all electoral legislation, based on organs within each state, would have to be modified.

\subsection{The National Deputy}

Breaking the same paradigm, and going beyond the more obvious ideas, there is the suggestion of the national deputy. The idea would be to allow candidates to have votes in all states, forming a single voting list across the country. This would end the limitation of the electoral district to the state. In my view, this procedure would be compatible with the idea that the lower house should represent the entire population, not the states.

In today's world, communication among citizens occurs mainly in virtual environments, such as television and the internet, which do not observe territorial barriers. It is common for a person to be known and admired throughout the country, regardless of territorial division into states. Thus, it seems fair that this person can receive votes nationally, that is, by citizens of different states.

The adoption of this system as the only form of election of representatives could generate some apparently negative consequences, such as the fact that citizens of smaller constituent units would be represented only in the upper chamber. According to the approach of this work, this would not be real, since these citizens would always have some participation in the election of the national deputy, even when such a deputy comes from a state different from that of the voter. It is important to reinforce that the territorial division of Brazil does not correspond to the allocation of ethnic, religious, linguistic or any other minorities that require special protection from federalism. Furthermore, these minorities, spread across the whole country, could sum 
votes nationally, in order to elect a representative and successfully have a voice in the parliament.

In Brazil, national minorities are also local minorities. In fact, if a minority group is scattered across the country, it is more likely to achieve some representation if it can elect a deputy nationally, uniting the votes of its members throughout the country. In this context, invisible minorities in the country, united by a common problem (for example, disabled people) could elect one or more representatives, adding their votes nationally. With the modern media and virtual communication, it is reasonable to assume that these groups could unite nationally, even though they are physically distant.

However, as a way of experiencing this novelty in a gradual way, a mixed formula would also be possible. In this way, part of the deputies would be elected by their states of origin and others nationally.

As seen in previous sections, the mainstream ideas in federalism point to a direct relationship between federalism and democracy. The one person, one vote principle, in turn, is usually pointed out as essential to the equal representation of citizens in a democratic regime. In this chapter, I developed a specific point, the distortion in the representation of citizens in the lower chamber of a federal state, looking at the Brazilian case.

The first point, quite evident, is that the existence of an upper chamber with identical representation of all states (without proportionality) already represents inequality, to the detriment of the inhabitants of the most populous states.

This inequality of representation in the upper chamber, however, brings some important advantages to federalism, such as stability between constituent units. In the federal states, the upper chamber plays an important role in ensuring stability and, ultimately, in maintaining federation cohesion.

However, even in the lower house, which should represent the population equally, the simple fact of dividing the population into electoral districts equivalent to the states is enough to create a distortion in the equality of representation.

Therefore, although under and overrepresentation can also occur in nonfederal states, the limits of federal organisation (especially the election of representatives in the strict limits of a constituent unit), by itself, already causes inequality in representation of citizens. 
The problem can still be aggravated, for several reasons, but mainly by the establishment of the minimum and maximum number of representatives. In the Brazilian case, this distortion is large and evident.

To reduce the problem, it would be advisable to eliminate the maximum of representatives and keep a minimum of one, establishing an almost absolute proportion, as far as mathematically possible. This would not necessarily mean an increase in parliament size. The idea here is to modify the division of chairs, without a maximum for each constituent unit (and the minimum of one), while maintaining the total number.

In addition, the adoption of bilateral discussion mechanisms can open important channels for dialogue. This would not eliminate distortion in representation, but it could give citizens of underrepresented states more voice. Also, the establishment of electoral districts different from the borders of the constituent units, in order to counterbalance differences in population density, would mitigate the problem.

Finally, a possible proposal would be the idea of the national deputy, elected with votes from all over the country, without being limited to a state. This formula could be used for the entire lower chamber, or, in different degrees, in mixed formulas, where part of the deputies would be elected by their states of origin and others nationally.

\section{Bibliography}

Anderson, George. Federalismo: uma introdução. Rio de Janeiro: FGV, 2009.

Burgess, Michael and Gagnon, Alain-G. Comparative Federalism and Federation. London: Harvester Wheatsheaf, 1993.

Elazar, Daniel. Exploring Federalism. Tuscaloosa:The University of Alabama Press, 1987. Farber, Daniel A., Eskridge, William N. Jr. And Frickey, Philip P. Constitutional Law. St. Paul: Thomson West, 2003.

Fleiner, Thomas, Alexander Misic and Nicole Töpperwien. Constitutional Law in Switzerland. Alphen aan den Rijn: Stämpfli Publishers, 2012.

Hamilton, Alexander, John Jay and James Madison. The Federalist. Edited by George W. Carey and James McClellan (2001). http://files.libertyfund.org/files/788/oo84_ LFeBk.pdf.

Hueglin, Thomas and Alan O. Fenna. Comparative Federalism: A Systematic Inquiry. Quebec: Broadview Press, 2005.

King, Preston. Federalism and Federation. Baltimore: The Johns Hopkins University Press, 1982. 
Nicolau, Jairo. Representantes de quem? Os descaminhos do seu voto da urna à Câmara dos Deputados. Rio de Janeiro: Zahar, 2017.

Palermo, Francesco. "Beyond Second Chambers: Alternative Representation of Territorial Interests and Their Reasons." Perspectives on Federalism 10, no. 2 (2018): E-49-E-7o.

Piancasteli, Marcelo. “The Federal Republic of Brazil”. In Distribution of Powers and Responsibilities in Federal Countries, edited by Akhtar Majeed, Ronald L. Watts and Douglas M. Brown, 66-9o. Montreal. McGill-Queen's University Press, 2006.

Sanchez Agesta, Luis. Curso de derecho constitucional comparado. Madrid: Universidad de Madrid, Facultad de Derecho, 1976.

Snyder, Richard and Samuels, David J. "Legislative Malapportionment in Latin America." In Federalism and Democracy in Latin America, edited by Edward L. Gibson, 29-84. Baltimore: The Johns Hopkins University Press, 2004.

Stepan, Alfred. "Toward a New Comparative Politics of Federalism, Multinationalism and Democracy." In Federalism and Democracy in Latin America, edited by Edward L. Gibson, 29-84. Baltimore: The Johns Hopkins University Press, 2004.

Watts, Ronald L. Comparing Federal Systems. Montreal: McGill-Queen's University Press, 2008. 